\title{
Cultural Resources Monitoring for the San Antonio Water Systems Sewer Line Repair Project, San Antonio, Bexar County, Texas
}

Chris Matthews

Lindy Martinez

Follow this and additional works at: https://scholarworks.sfasu.edu/ita

Part of the American Material Culture Commons, Archaeological Anthropology Commons, Environmental Studies Commons, Other American Studies Commons, Other Arts and Humanities Commons, Other History of Art, Architecture, and Archaeology Commons, and the United States History Commons

Tell us how this article helped you.

This Article is brought to you for free and open access by the Center for Regional Heritage Research at SFA ScholarWorks. It has been accepted for inclusion in Index of Texas Archaeology: Open Access Gray Literature from the Lone Star State by an authorized editor of SFA ScholarWorks. For more information, please contact cdsscholarworks@sfasu.edu. 


\section{Cultural Resources Monitoring for the San Antonio Water Systems Sewer Line Repair Project, San Antonio, Bexar County, Texas}

\section{Creative Commons License}

\section{(c) (1) (8)}

This work is licensed under a Creative Commons Attribution-NonCommercial 4.0 International License 


\title{
CULTURAL RESOURCES MONITORING FOR THE SAN ANTONIO WATER SYSTEMS SEWER LINE REPAIR PROJECT, SAN ANTONIO, BEXAR COUNTY, TEXAS
}

\author{
FINAL REPORT (Redacted) \\ Prepared for: \\ San Antonio Water Systems \\ 2800 US-281 \\ San Antonio, Texas 78212 \\ Prepared by: \\ Chris Matthews and \\ Lindy Martinez

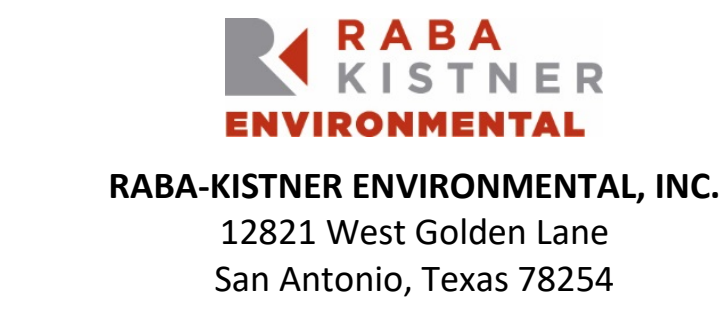 \\ Principal Investigator \\ Antonio E. Padilla
}

Texas Antiquities Committee Permit Number: 9209

Cultural Resources Report No. 20-001

ASF19-165-00

April 6, 2020 


\section{ABSTRACT}

Raba Kistner, Inc. (RKI) was contracted by K-Friese + Associates (CLIENT), on behalf of San Antonio Water Systems (SAWS) to conduct archaeological monitoring for emergency repairs to a collapsed sewer lateral within West Houston Street in downtown San Antonio, Bexar County, Texas. The project involved the excavation of the area around the collapsed portion of the sewer lateral and the replacement of the damaged line. The project is located within the boundaries of a Catholic Cemetery and is between Milam Square (41BX991), which is a historic cemetery, and an area of the Children's Hospital of San Antonio where the first City Cemeteries have been documented. As such, the City of San Antonio Office of Historic Preservation (COSA OHP) required the monitoring of the excavation activities.

The proposed project is located on lands controlled by the City of San Antonio and work was conducted by SAWS, both entities of the State of Texas. As such, the project falls under the Antiquities Code of Texas (ACT) (Texas Natural Resource Code, Title 9, Chapter 191). Furthermore, the project was also subject to review under Chapter 35 of the City of San Antonio's Unified Development Code (UDC) (Article VI, Historic Preservation and Urban Design). All work was conducted in accordance with the Archeological Survey Standards for Texas as set forth by the Council of Texas Archeologists (CTA) and the THC under Texas Antiquities Committee Permit Number 9209.

A desktop review was conducted to determine if any previously conducted archaeological investigations or any cultural resources had been documented within the APE. Review of the Texas Archeological Sites Atlas (Atlas), revealed that no previous archaeological surveys have been conducted within the APE and that no previously recorded archaeological sites have been documented within the APE.

Cultural resources monitoring investigations for the project were conducted on December 21 and 22, 2019, and January 14, 2020. Antonio Padilla served as Project Manager and Principal Investigator, and all field work was conducted by Lindy Martinez and Susan Sincerbox. The undertaking involved the excavation of an approximately 34-foot-long (10 meter [m]-) north-south, 2.5-to-9-foot-wide east-west (0.5-to-2.74 m-) trench that extended from the sewer main located near the center of West Houston Street to the clean out located under the sidewalk north of West Houston Street. For archaeological purposes the Area of Potential Effects (APE) consisted of approximately 800 square feet or 0.018 acres. The depths of impacts reached a depth of 6 feet $(1.8 \mathrm{~m})$ below surface. 
During the investigations, it was discovered that the entire APE has been heavily impacted by previous construction events and the installation of utilities. Throughout the excavations, construction gravels reaching a depth of 6 feet $(1.8 \mathrm{~m})$ below surface were observed within the entire APE, and several utilities were encountered. No intact soils were present within the trench. It appears that previous construction events and installation of utilities have removed all intact soils to the depth reached by the trench. Due to the absence of intact soils, no soils were screened. Additionally, no cultural materials or cultural features were observed during the monitoring of the excavations.

RKI has made a reasonable and good faith effort identifying cultural resources within the APE. No significant deposits or features were identified during cultural resource monitoring. As a result, RKI does not recommend further archaeological investigations within the APE. However, should changes be made to the APE, further work may be required. No diagnostic artifacts were collected during the course of the investigations, thus, no artifacts will be curated at the completion of the project. All field records generated during this project will be permanently curated at the Center for Archaeological Research at the University of Texas at San Antonio. 


\section{TABLE OF CONTENTS}

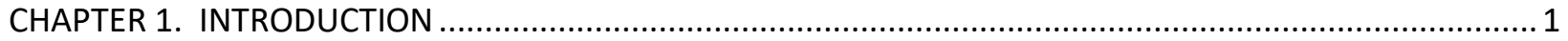

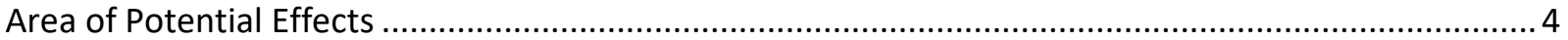

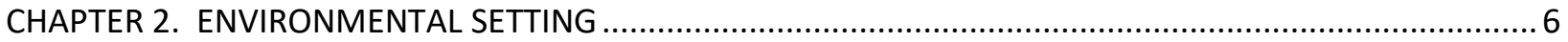

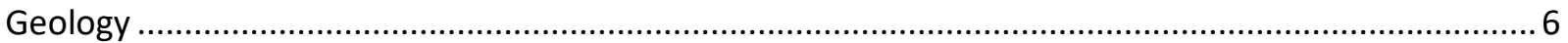

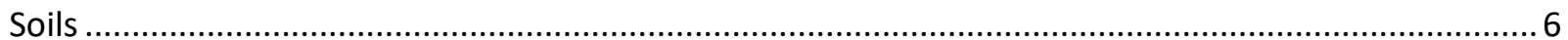

CHAPTER 3. CULTURAL CONTEXT

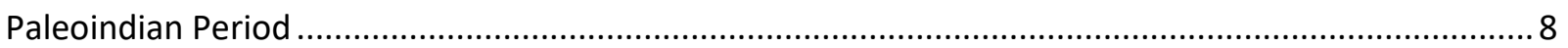

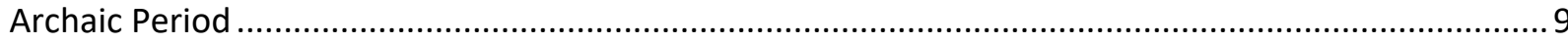

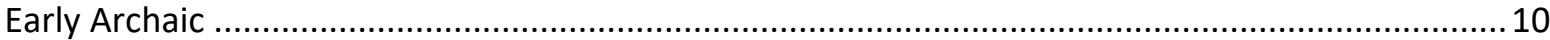

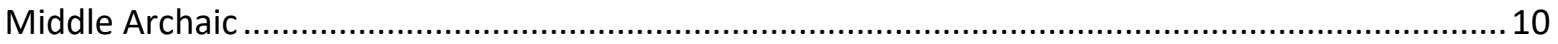

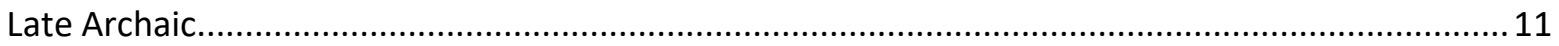

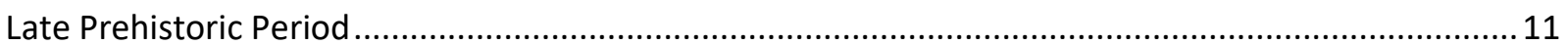

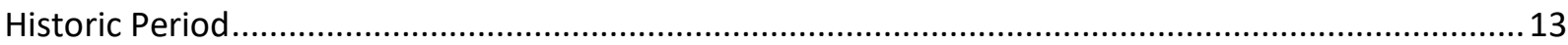

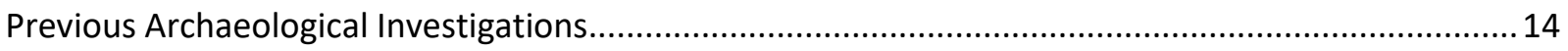

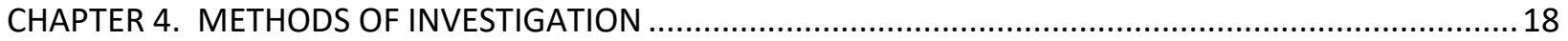

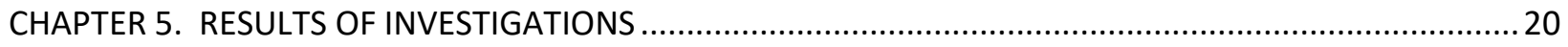

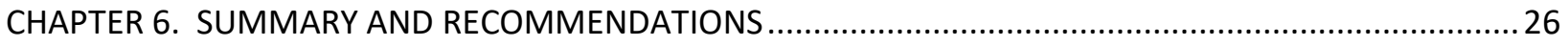

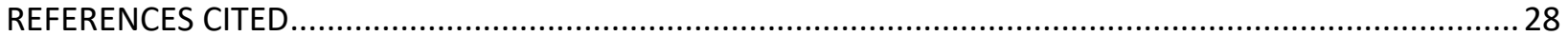




\section{LIST OF FIGURES}

Figure 1-1. Project Area location in downtown San Antonio, Bexar County, Texas.................................. 2

Figure 1-2. Project location (Area of Potential Effects) in relation to the Catholic and City Cemeteries..... 3

Figure 1-3. The Area of Potential Effects depicted on the San Antonio East (2998-133), Texas 7.5-minue United States Geological Survey (USGS) topographic quadrangle map....................................... 5

Figure 2-1. Overview of the Project Area and APE with soils. ............................................................ 7

Figure 3-1. Previously documented archaeological investigations and cultural resources within 1,000-feet

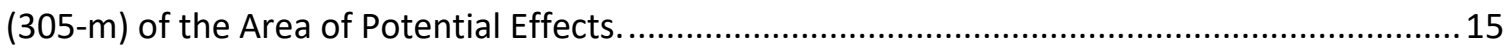

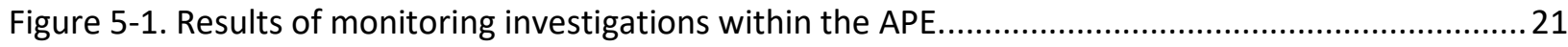

Figure 5-2. Overview of the Area of Potential Effects; facing east/southeast. ........................................ 22

Figure 5-3. Overview of the Area of Potential Effects; facing southwest................................................ 22

Figure 5-4. Disturbances observed during the excavation of the main trench; facing northwest.............23

Figure 5-5. Figure 5-5. Typical profile of the main trench; facing south............................................2 23

Figure 5-6. Construction gravels and utilities observed in the smaller trench, facing west......................24

\section{LIST OF TABLES}

Table 3-1. Previously Recorded Archaeological Sites within 1,000-feet (305 m) of the Area of Potential Effects. 16

Table 3-2. Historical Markers within 1,000 feet $(305 \mathrm{~m})$ of the Area of Potential Effects. ....................... 16

Table 3-3. National Register Districts within 1,000 feet (305-m) of the Area of Potential Effects. 16 


\section{CHAPTER 1. INTRODUCTION}

Raba Kistner, Inc. (RKI) was contracted by K-Friese + Associates (CLIENT), on behalf of San Antonio Water Systems (SAWS), to conduct archaeological monitoring for emergency repairs to a collapsed sewer lateral within West Houston Street in Downtown San Antonio, Bexar County, Texas (Figure 1-1). The project involved the excavation of the area around the collapsed portion of the sewer lateral and the replacement of the damaged line. The project is located within the boundaries of a Catholic Cemetery and is between Milam Square (41BX991), which is a historic cemetery, and an area of the Children's Hospital of San Antonio where the first City Cemeteries have been documented (Figure 1-2). As such, the City of San Antonio Office of Historic Preservation (COSA OHP) required the monitoring of the excavation activities.

The proposed project is located on lands controlled by the City of San Antonio and work was conducted by SAWS, both entities of the State of Texas. As such, the project fell under the Antiquities Code of Texas (ACT) (Texas Natural Resource Code, Title 9, Chapter 191). Furthermore, the project was also subject to review under Chapter 35 of the City of San Antonio's Unified Development Code (UDC) (Article VI, Historic Preservation and Urban Design). These legislations call for assessment of all proposed improvement activities that have the potential to disturb historically significant resources and significant subsurface deposits on lands owned by the State or one of its political subdivisions (Texas Natural Resources Code, Title 9, Chapter 191; COSA UDC, Chapter 35). The Texas Historical Commission (THC) administers oversight of compliance with the ACT, while the COSA OHP provides compliance with Chapter 35 of the UDC.

Investigations consisted of archaeological monitoring of ground disturbing activities associated with the repairing of the broken sewer line. Archaeological monitoring was conducted on behalf of the CLIENT to satisfy the requirements of the ACT and the UDC. The purpose of the investigations was to identify any subsurface cultural deposits and any potential human remains within the limits of the proposed undertaking, and, if possible, access their significance and eligibility for inclusion in the National Register of Historic Places (NHRP) and for formal designation as State Antiquities Landmarks (SAL).

The archaeological monitoring investigations were conducted on December 21 and 22, 2019 and January 14, 2020. Antonio E. Padilla served as the Principal Investigator, while Staff Archaeologist Lindy Martinez and Bioarchaeologist Susan Sincerbox performed the archeological monitoring for the project. All work was conducted in accordance with the Archeological Survey Standards for Texas as set forth by the Council of Texas Archeologists (CTA) and the THC under Texas Antiquities Committee Permit Number 9209. 


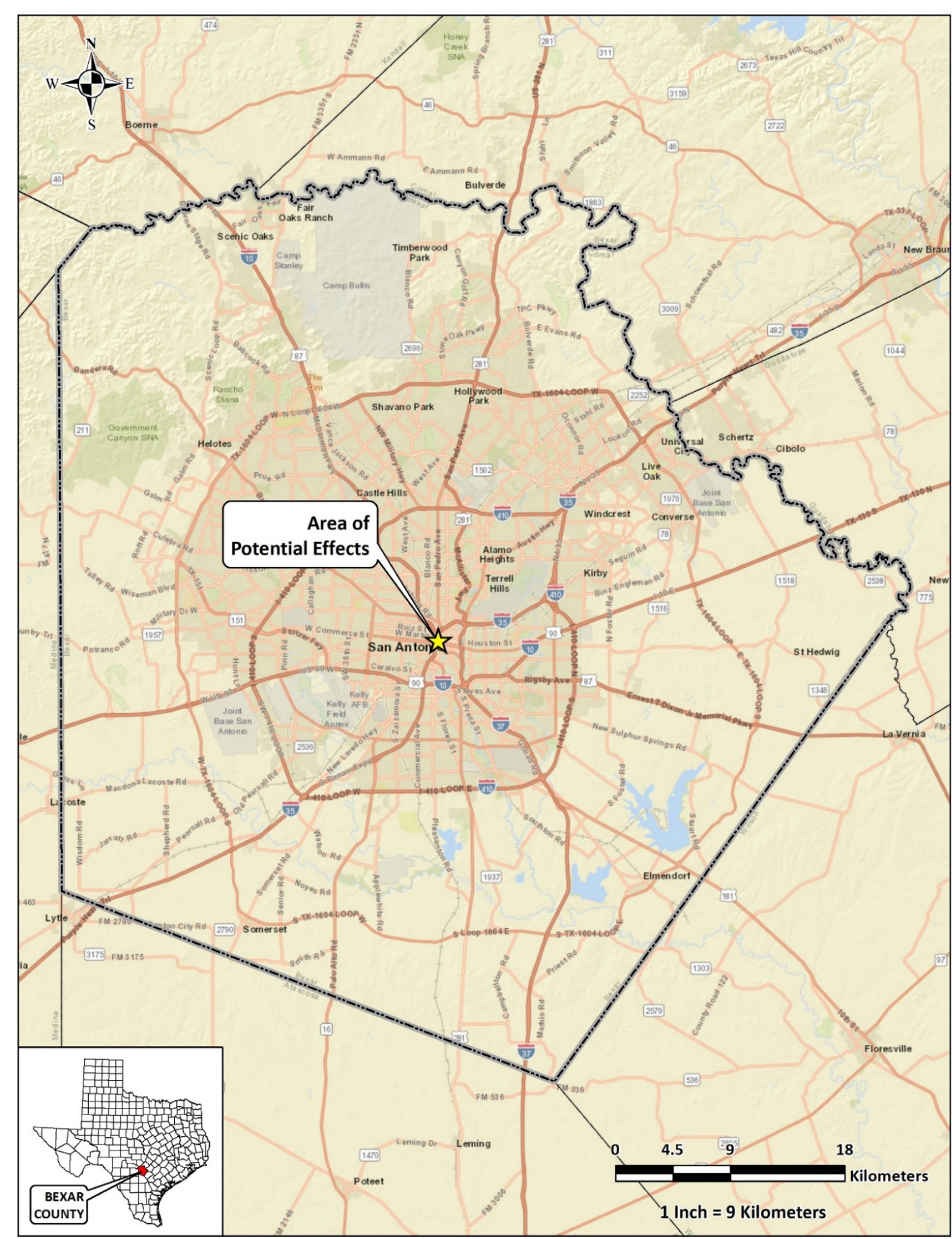

Figure 1-1. Project Area location in downtown San Antonio, Bexar County, Texas. 


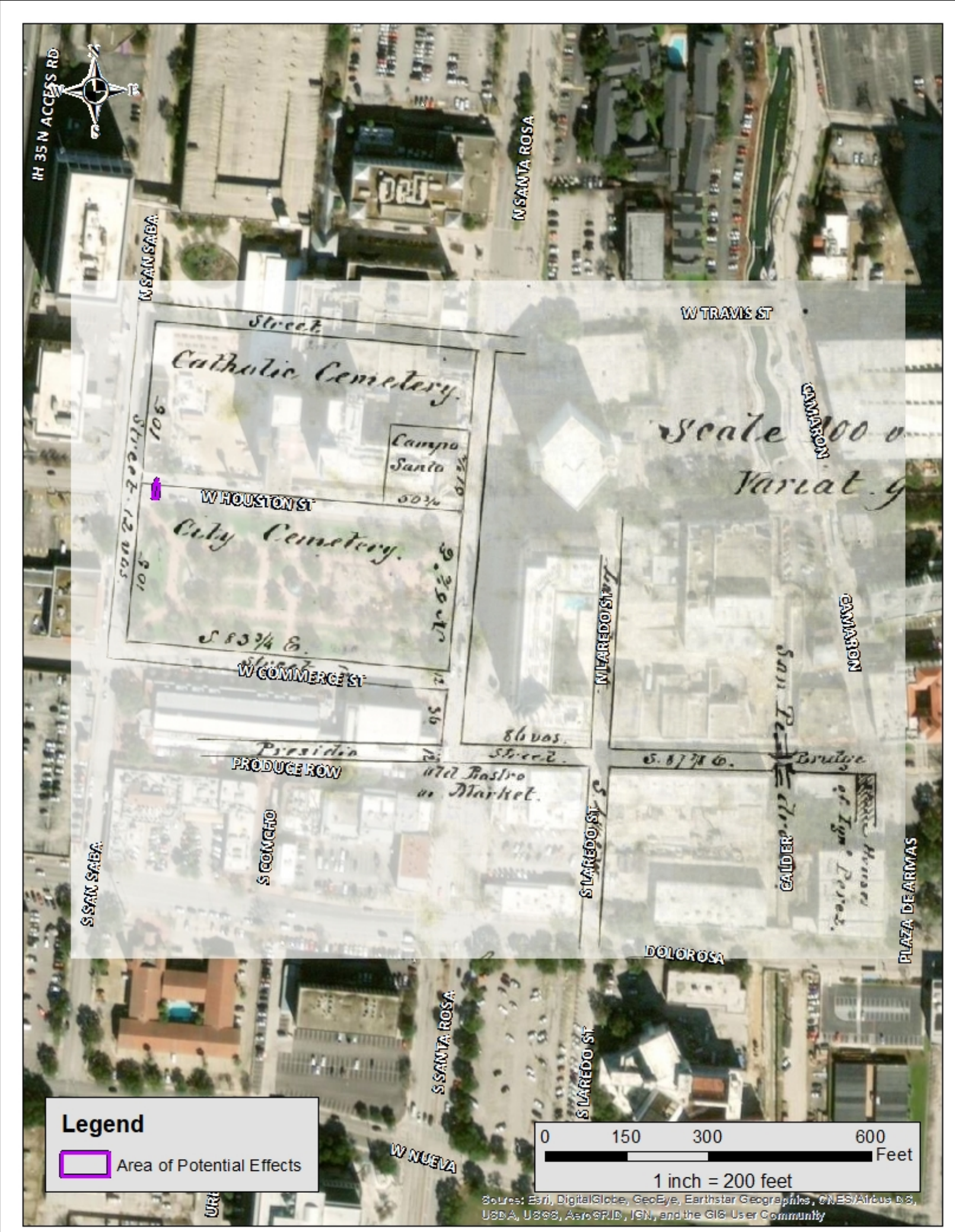

Figure 1-2. Project location (Area of Potential Effects) in relation to the Catholic and City Cemeteries. 


\section{Area of Potential Effects}

The proposed project is located within West Houston Street between Milam Park and the San Antonio Children's Hospital, approximately 18-feet $(5.5 \mathrm{~m}$ ) east of the intersection of North San Saba and West Houston Street. The undertaking involved the excavation of an approximately 34-foot-long (10-meters [m]) north-south, 2.5-to-9-foot-wide east-west (0.5-to-2.74-m-) trench that extended from the sewer main located near the center of West Houston Street to the clean out located in the sidewalk north of West Houston Street. For archaeological purposes, the Area of Potential Effects (APE) comprised the excavated approximately 34 feet $(10 \mathrm{~m})$ north-south by 2.5 -to-9 feet $(0.5-$ to- $2.74 \mathrm{~m})$ east-west trench, totaling 0.018 acres (0.007 hectares) (Figure 1-3). The depths of impacts reached 6 feet $(1.8 \mathrm{~m})$ below surface.

At the time of excavations, the project area was located within a highly developed urban setting composed of an asphalt road and cement sidewalk as well as multiple existing utilities that intersected the trench. The APE is depicted on the San Antonio East (2998-133), Texas 7.5-minute United States Geological Survey (USGS) topographic quadrangle map (see Figure 1-3). 


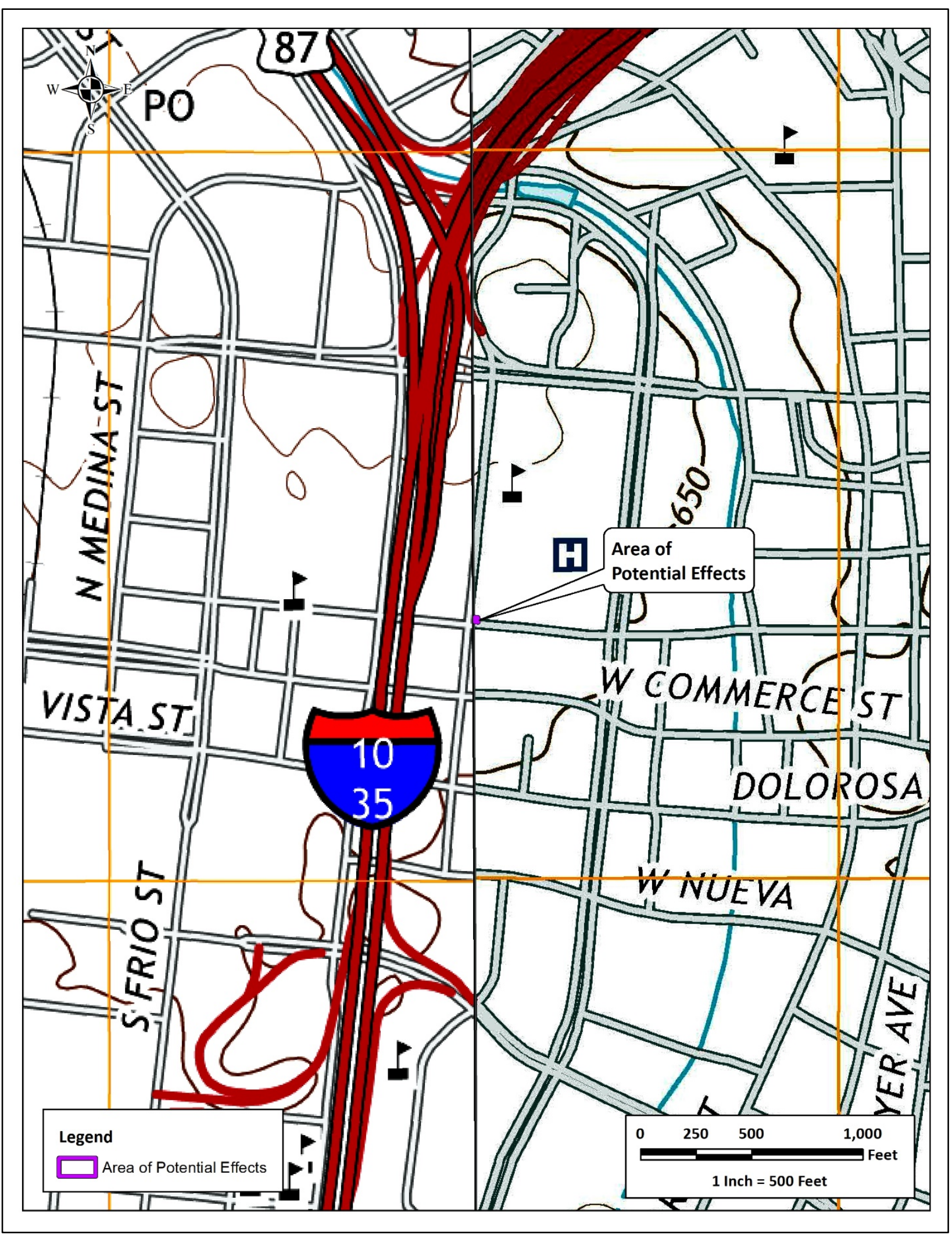

Figure 1-3. The Area of Potential Effects depicted on the San Antonio East (2998-133), Texas 7.5minue United States Geological Survey (USGS) topographic quadrangle map. 


\section{CHAPTER 2. ENVIRONMENTAL SETTING}

The project is located within the south-central Texas geographic region within the Blackland Prairie ecoregion. The Blackland Prairie is an area of low topographic relief and poor drainage that is prone to frequent flooding (Collins 1995). The Blackland Prairie physiographic region is characterized by gently undulating topography and is generally defined as grasslands punctuated by riparian bands along creeks, rivers, and other drainages. Generation of the Blackland Prairie occurred during the late Tertiary with the erosions of soils on the Edwards Plateau. These soils were deposited by eolian and colluvial processes across an existing, eroded parent material of the Gulf Coastal Plain, creating a mix of deep Tertiary and Quaternary calcareous clay soils (Black 1989a).

\section{Geology}

The project area is underlain by a single geological unit: Terrace deposits (Qt). The deposits consist of late Quaternary sands, silts, clays and gravels that comprise terraces inset to upper Cretaceous clays and mudstones of the Navarro Group and Marlbrook Marl (Knb) (Bureau of Economic Geology 1983). Gravel percentages within the terrace deposits vary with higher terraces containing more gravels than the lower terraces, which are typically capped with clayey silts and sands that are 6.5 to 13 feet (2 to 4 meters $[\mathrm{m}])$ thick. The terrace deposits are locally indurated with calcium carbonate, which illustrates their great antiquity.

\section{Soils}

Soils mapped within the APE belong to the Branyon Series (Natural Resources Conservation Service (NRCS) 2019) (Figure 2-1). The Branyon clay, 0 to 1 percent slopes (HtA) occupy the Project Area. Branyon soils are Vertisols that are characterized as very deep (up to 6.7 feet [203 centimeters] thick), moderately well-drained soils that are slowly permeable (NRCS 2019). These soils form in calcareous clayey alluvium derived from mudstones of Pleistocene age deposits on nearly level to very gently sloping stream terrace surfaces. 


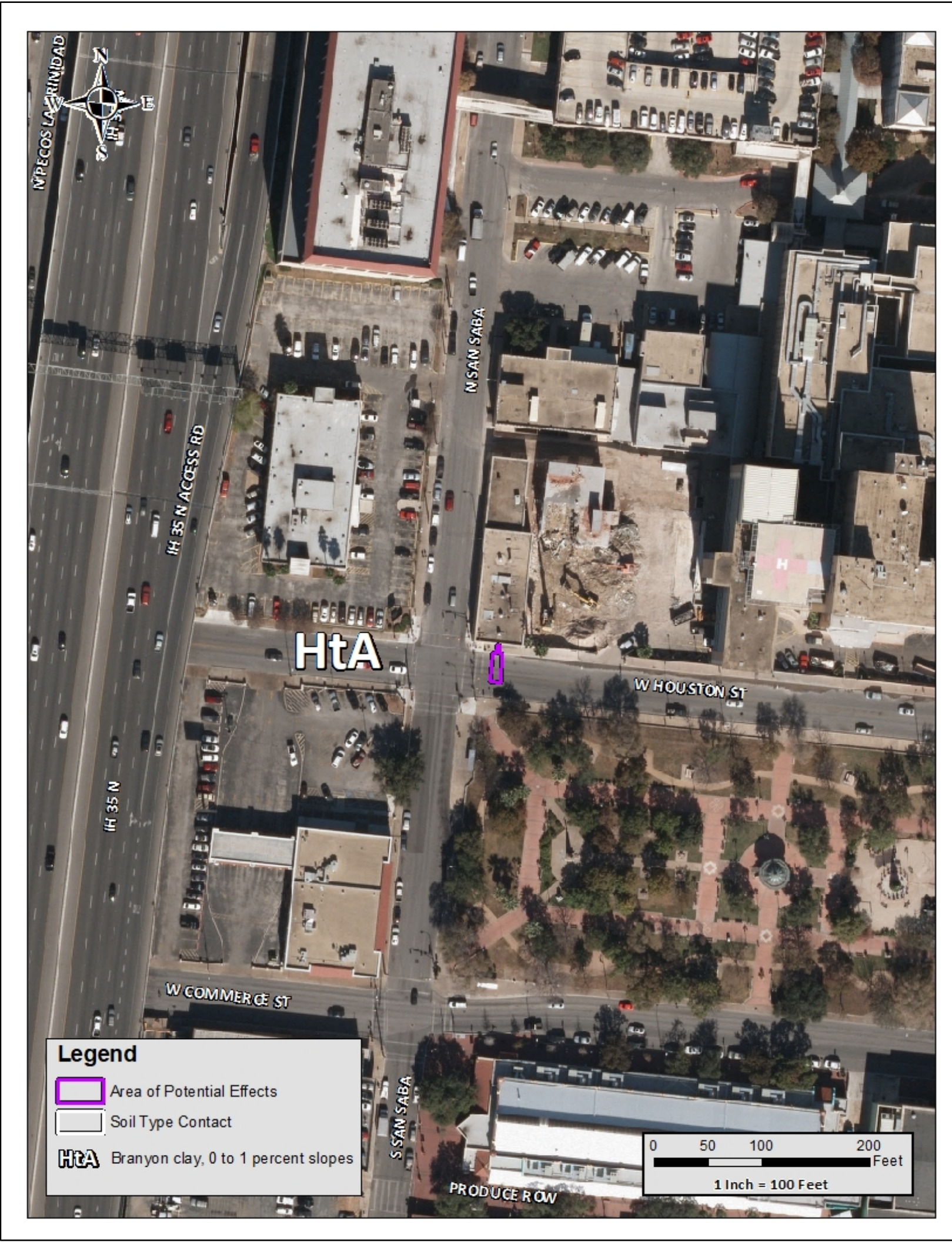

Figure 2-1. Overview of the Project Area and APE with soils. 


\section{CHAPTER 3. CULTURAL CONTEXT}

The SAWS Sewer Line Repair Project area is located at the cusp of the Central Texas and South Texas archaeological regions (Turner and Hester 1999). Based on extensive research conducted by Black (1989b), Collins (1995, 2004), Hester (2004), Johnson et al. (1962), Prewitt (1981, 1985), Sorrow et al. (1967), Suhm (1957, 1960), Suhm et al. (1954), and Weir (1976), Central Texas has a well-established chronological sequence beginning 12,000 years ago. The sequence for South Texas is less defined, though the Project Area likely shares many of the attributes identified for Central Texas. Nonetheless, the chronological sequence of Bexar County and the vicinity is divided in to four cultural periods, spanning approximately 11,500 years. Archaeologists have divided the occupation of the region into four principal periods and several sub-periods: Paleoindian (11,500-8800 B.P.), Archaic (8000-1200 B.P.), Late Prehistoric (1200-400 B.P.), and Historic (400 B.P. to present). The periods are characterized by changes climatic conditions, distinct vegetation types and structure, and concomitant adaptive changes by human populations in hunting and gathering technologies and strategies, general material culture, and at the tail end of the cultural sequence, the arrival of non-indigenous populations.

\section{Paleoindian Period}

The oldest cultural materials found in the region date to the Paleoindian period. The period spans roughly from 11,500-8,800 B.P. (Collins 1995, 2004). The Aubrey site in Denton County has one of the earliest occupations, with radiocarbon assays dating to between 11,542 \pm 11 B.P. and 11,590 \pm 93 B.P. (Bousman et al. 2004:48). Paleoclimatic proxy measures suggest that a cooler climate with increased precipitation was predominant during the Late Pleistocene (Mauldin and Nickels 2001; Toomey et al. 1993), the later portion of the period.

Initial reconstructions of Paleoindian adaptations typically viewed these hunter-gatherers as traversing extreme distances in pursuit of now extinct mega-fauna such as mammoth and mastodon. While these Paleoindian populations did exploit the Late Pleistocene mega-fauna when it was accessible, a number of faunal assemblages from a larger number of sites indicate that the Paleoindian diet was more varied and consisted of a wide range of resources, including small game and plants. The Lewisville (Winkler 1982) and the Aubrey sites (Ferring 2001) produced faunal assemblages that represented a wide range of taxa, including large, medium, and small species. Information on the consumption of plant resources during the 
Paleoindian period is lacking. Bousman et al. (2004) reported that the late Paleoindian component at the Wilson-Leonard site reflected the exploitation of riparian, forest, and grassland species. Analysis of Paleoindian skeletal remains indicates that the diets of the Paleoindian and later Archaic hunter-gatherers may have been similar (Bousman et al. 2004; Powell and Steele 1994).

The early portion of the Paleoindian period was characterized by the appearance of Clovis and Folsom fluted projectile points that were used for hunting mega-fauna. Typical projectile points produced at sites with occupations dating to the later portion of the Paleoindian period included the Plainview, Dalton, Angostura, Golandrina, Meserve, and Scottsbluff types. Meltzer and Bever (1995) have identified 406 Clovis sites in Texas. One of the earliest, 41RB1, yielded radiocarbon assays that put the maximum age for the Paleoindian component at 11,415 \pm 125 B.P. (Bousman et al. 2004:47).

Sites in Bexar County that contain Paleoindian components include St. Mary's Hall (Hester 1978, 1990), Pavo Real (Collins et al. 2003), the Richard Beene site (Thoms et al. 1996; Thoms and Mandel 2006) and 41BX1396 (Tomka 2012). St. Mary's Hall, 41BX229, was first encountered in 1972 during the construction of a house just outside the school's property. The Pavo Real site, 41BX52, is located along Leon Creek in northwest Bexar County. The site was first documented in 1970 and has been investigated several times over the past 40 years (Collins et al. 2003). The Richard Beene site, 41BX831, is located along the Medina River in southern Bexar County (Thoms et al. 1996). Site 41BX1396 is located in Brackenridge Park in San Antonio, and was encountered during installations for lighting in 2010. Dating of organic samples indicated that occupation at the site occurred as early as 10,490-10,230 B.P.

\section{Archaic Period}

The Archaic period dates between ca. 8,800 to 1,200 B.P. It is divided into three subperiods: Early, Middle, and Late. During the Archaic, mobility strategies may have shifted to more frequent short distance movements that allowed the exploitation of seasonal resource patches. The intermittent presence of bison in parts of Texas, combined with changes is climatic conditions and the primary productivity of the plant resources may have contributed to shifts in subsistence strategies and associated technological repertoire. When bison was not present in the region, hunting strategies focused on medium to small game along with continued foraging for plant resources. When bison was available, hunter-gatherers targeted the larger-bodied prey on a regular basis. 


\section{Early Archaic}

The Early Archaic spans from 8,800 to 6,000 B.P. (Collins 1995, 2004). Projectile point styles characteristic of the Early Archaic include Angostura, Early Split Stem, Martindale, and Uvalde (Collins 1995, 2004). The Early Archaic climate was drier than the Paleoindian period and witnessed a return to grasslands (Bousman 1998). Mega-fauna of the Paleoindian period could not survive the new climate and ecosystems, therefore eventually dying out. Early Archaic exploitation of medium to small fauna intensified.

The excavations at the Wilson-Leonard site (41WM235) produced a wealth of cultural materials representative of a lengthy period in regional prehistory. The projectile point assemblages from the site indicate that the lanceolate Paleoindian point forms continue from the Paleoindian into the Early Archaic (Angostura). However, relatively quickly during the Early Archaic, they are replaced by corner- and basallynotched and shouldered forms (Early Triangular, Andice, Bell) that quickly become the dominant points tipping the atlatl-thrown darts. In addition, the uses of small to medium hearths similar to the previous period were noted. The appearance of earth ovens suggests another shift in subsistence strategies. The earth ovens encountered at the Wilson-Leonard site were used to cook wild hyacinth along with aquatic and terrestrial resources (Collins et al. 1998). Analyses of Early Archaic human remains encountered in Kerr County (Bement 1991) reveal diets low in carbohydrates in comparison to the Early Archaic populations found in the Lower Pecos region.

\section{Middle Archaic}

The Middle Archaic sub-period spans from 6,000 to 4,000 B.P. (Collins 1995, 2004; Weir 1976). Archaeological data indicates that there appeared to be a population increase during this time. The climate was gradually drying leading to the onset of a long drought period. Changes to the demographics and cultural characteristics were likely in response to the warmer and more arid conditions. Projectile point styles characteristic of this sub-period include Bell, Andice, Calf Creek, Taylor, Nolan, and Travis.

Subsistence during the Middle Archaic saw an increased reliance on nuts and other products of riverine environments (Black 1989b). The increase of burned rock middens during the Middle Archaic represented the increased focus on the use of plant resources (Black 1989b; Johnson and Goode 1994). Little is known about burial practices during the Middle Archaic. An excavation in an Uvalde County sinkhole (41UV4) contained 25-50 individuals (Johnson and Goode 1994:28). 


\section{Late Archaic}

The Late Archaic spans from 4,000 to 1,200 B.P. (Collins 1995, 2004). It is represented by the Bulverde, Pedernales, Kinney, Lange, Marshall, Williams, Marcos, Montell, Castroville, Ensor, Frio, Fairland, and Darl projectile points. The early part of the Late Archaic exhibited fluctuations in the temperature and rainfall. There appears to have been an increase in population at this time (Nickels et al. 1998).

Some researchers believe that the use of burned rock middens decreased during the Late Archaic. Some research has challenged this notion (Black and Creel 1997; Mauldin et al. 2003). Johnson and Goode (1994) discuss the role of burned rock middens in relation to acorn processing.

Human remains from burials related to the Late Archaic in Central and South Texas suggest the region saw an increase in population. This increase may have prompted the establishment of territorial boundaries which resulted in boundary disputes (Story 1985). Human remains dating to this sub-period have been encountered near the Edwards Plateau.

\section{Late Prehistoric Period}

The Late Prehistoric period begins ca. 1,200 B.P. (Collins 1995, 2004), and appears to continue until the beginning of the Protohistoric period (ca. A.D. 1700 for Bexar County). The term Late Prehistoric is used in Central and South Texas to designate the time following the end of the Archaic period. A series of traits characterizes the shift from the Archaic to the Late Prehistoric period. The main technological changes were the shift to the bow and arrow and the introduction of pottery. The Late Prehistoric period is divided into two phases: the Austin phase and the Toyah phase.

At the beginning of this period, environmental conditions were deemed to be warm and dry. Moister conditions appear after 1,000 B.P. (Mauldin and Nickels 2001). Subsistence practices appeared similar to the Late Archaic. Projectile points associated with the Austin phase include the Scallorn and Edwards types. The Toyah phase is characterized by the prominence of the Perdiz point (Collins 1995, 2004).

Most researchers concur that the early portion of the Late Prehistoric period saw a decrease in population density (Black 1989b:32). Radiocarbon dates from some sites have indicated that the middens were utilized during the Late Prehistoric. Some archaeologists feel the peak of midden use was after A.D. 1 and into the Late Prehistoric (Black and Creel 1997:273). Radiocarbon dates from Camp Bowie middens 
provide evidence that supports Black and Creel's arguments that burned rock middens were a primarily Late Prehistoric occurrence (Mauldin et al. 2003).

Beginning rather abruptly at about 650 B.P., a shift in technology occurred. This shift is characterized by the introduction of blade technology, the first ceramics in Central Texas (bone-tempered plainwares), the appearance of Perdiz arrow points, and alternately beveled bifaces (Black 1989b:32; Huebner 1991:346). Prewitt (1981) suggests this technology originated in north-central Texas. Patterson (1988), however, notes that the Perdiz point was first seen in southeast Texas by about 1,350 B.P., and was introduced to west Texas some 600 to 700 years later.

Early ceramics in Central Texas (ca. A.D. 1250 to 1300) are associated with the Toyah phase of the Late Prehistoric and are referred to as Leon Plain ware. The Leon Plain ceramic types are undecorated, bonetempered bowls, jars, and ollas with oxidized, burnished, and floated exterior surfaces (Ricklis 1995). There is notable variation within the type (Black 1986; Johnson 1994; Kalter et al. 2005). This variation can be attributed to differences in manufacturing techniques and cultural affiliation. Analysis of residues on ceramic sherds suggests that vessels were used to process bison bone grease/fat, mesquite bean/bison bone grease and deer/bison bone grease (Quigg et al. 1993).

The return of bison to South and Central Texas during the Late Prehistoric resulted from a drier climate in the plains located to the north of Texas and increased grasses in the Cross-Timbers and Post Oak Savannah in north-central Texas (Huebner 1991). The increased grasses in the two biotas formed the "bison corridor" along the eastern edge of the Edwards Plateau and into the South Texas Plain (Huebner 1991:354-355). Rock shelter sites, such as Scorpion Cave in Medina County (Highley et al. 1978) and Classen Rock Shelter in northern Bexar County (Fox and Fox 1967), have indicated a shift in settlement strategies (Skinner 1981). Burials encountered that dated to this period often reveal evidence on conflict (Black 1989b:32). 


\section{Historic Period}

The beginnings of San Antonio came about with the establishment of Mission San Antonio de Valero in 1718. Fray Antonio de San Buenaventura y Olivares briefly visited the site several years prior, and petitioned to set up a mission at the headwaters of the San Antonio River to act as a waypoint in the journey to East Texas. The Marques de Valero, Viceroy of New Spain, granted Olivares' request (de la Teja 1995). The mission, presidio, and villa were first established on the San Pedro Creek, the "first spring" of the San Antonio River. Mission Valero occupied at least one other location on the east side of the San Antonio River before it was moved in 1724 to its final location.

Four days after Mission Valero was founded, Presidio de Bexar was established on May 5, 1718. The presidio was to house the Spanish soldiers who had come along with the expedition to found the Mission. Typically, the families that followed the soldiers lived just outside the presidio.

Two years later, in 1720, Mission San José y San Miguel de Aguayo was established on the opposite bank of the San Antonio River, and to the south of Mission Valero and Presidio San Antonio de Bexar. This mission was established to help serve native groups that did not want to reside at Mission Valero because they were not on friendly terms with groups already living there. The original location of Mission San José was along the east bank of the San Antonio River, approximately three leagues from Mission Valero. The mission was then moved to the opposite bank sometime between 1724 and 1729, and relocated to its present site during the 1740s due to an epidemic (Scurlock et al. 1976:222).

In 1722, just two years after Mission San José was founded, Mission San Francisco Xavier de Nàjera was established. The mission was to serve a group of 50 Ervipiami families that came from the Brazos River area (Schuetz 1968:11). Mission San Francisco Xavier de Nàjera was located on or near the present site of Mission Concepción. The mission was unsuccessful due to a lack of funding. An attempt was made to make the mission a sub-mission of Valero, but this failed as well (Habig 1968:78-81). Its doors closed in 1726 (Schuetz 1968:11). Ivey (1984:13) argued that the closure of the mission was due to the natives' lack of interest in entering mission life.

Within the next few years, three other missions were established within the San Antonio area. The remaining three missions were established in San Antonio within weeks of each other in 1731 . These three missions, Mission Nuestra Señora de la Purisima Concepción, Mission San Juan de Capistrano, and 
Mission San Francisco de la Espada, were originally missions established in east Texas. When each failed along the eastern border, they were moved to San Antonio.

In 1731, in addition to the five missions, Villa San Fernando de Bexar was established by the Canary Islanders. Prior to the establishment of Villa San Fernando, Villa de Bexar had been settled by 30 presidio soldiers, seven of whom were married and brought their families. Archival research indicates that upon arrival, the Canary Islanders immediately took over the land surrounding the garrison. This land was used as pasture and was originally property of Mission Valero. There had been a lack of cleared agricultural land at the time, leading Captain Juan Antonio Pérez de Almazán to allow the Canary Islanders use of the property (de la Teja 1995). The initial plan was for additional Canary Island settlers to be sent to San Antonio after the first group was established. Due to high costs to the Spanish Crown, no more groups were brought to Texas. The Canary Islanders launched a formal complaint against Mission Valero. In 1731, the Canary Islanders established their own villa, named San Fernando de Bexar, with their own church. The arrival of the Isleños resulted in the first clearly defined civilian settlement in San Antonio.

With the establishment of the San Antonio Missions, the Spanish constructed a system of acequias (irrigation ditches) utilizing local springs, streams, and the San Antonio River to supply water for the agricultural fields of the missions, personal use, and house hold purposes (Cox 2005; Porter 2009). The first acequias were simple, soil-lined, gravity-flow canals whose depressions can still be seen today in certain areas around central San Antonio (Cox et al. 1999). This system allowed the Spanish to sustain the large population of the Native Americans, settlers, and soldiers that occupied the area.

\section{Previous Archaeological Investigations}

RKI conducted a desktop review to determine if any previously conducted archaeological investigations or any cultural resources have been documented within the APE. Review of the Texas Archeological Sites Atlas (At/as), an online data base maintained by the THC, revealed that no previously archaeological surveys have been conducted and no previously record archaeological sites have been documented within the APE (Figure 3-1). A review of a 1,000-foot radius (305-meters [m]) of the APE identified five previously conducted surveys, two previously documented archaeological sites (41BX2092 and 41BX992), one of which (41BX992) is also a cemetery (Table 3-1). Additionally, two Official Texas Historical Markers (OTHM), 


\section{REDACTED}

Figure 3-1. Previously documented archaeological investigations and cultural resources within 1,000-feet (305-m) of the Area of Potential Effects. 
Cultural Resources Monitoring for the San Antonio Water Systems Sewer Line Repair Project,

and two National Register Districts were identified within 1,000-feet (305-m) of the APE (see Figure 3-1 and Tables 3-2 and 3-3).

Table 3-1. Previously Recorded Archaeological Sites within 1,000-feet (305 m) of the Area of Potential Effects.

\begin{tabular}{|c|c|c|c|c|}
\hline Resource & Site Name & Location & $\begin{array}{c}\text { NRHP/SAL } \\
\text { Designation }\end{array}$ & Description, Recorder/Year \\
\hline $41 \mathrm{BX992}$ & $\begin{array}{c}\text { Milam Square } \\
\text { Milam Park } \\
\text { Cemetery (BX- } \\
\text { C300) }\end{array}$ & $\begin{array}{c}95.6 \mathrm{ft} . \\
\mathrm{SE}\end{array}$ & Undetermined & $\begin{array}{c}\text { Cemetery, Historic. Recorded by the Center } \\
\text { for Archaeological Research at the University } \\
\text { of Texas at San Antonio (1995). }\end{array}$ \\
\hline $41 \mathrm{BX2092}$ & $\begin{array}{c}\text { Cattleman's } \\
\text { Square }\end{array}$ & $\begin{array}{c}460.3 \mathrm{ft} . \\
\mathrm{W}\end{array}$ & $\begin{array}{c}\text { Not Eligible/Not } \\
\text { Eligible }\end{array}$ & $\begin{array}{c}\text { Historic occupation. Recorded by Terracon } \\
\text { (2015). }\end{array}$ \\
\hline
\end{tabular}

Table 3-2. Historical Markers within 1,000 feet (305 m) of the Area of Potential Effects.

\begin{tabular}{|c|c|c|c|}
\hline Resource Type & $\begin{array}{c}\text { Distance/Direction from } \\
\text { Project Area }\end{array}$ & $\begin{array}{c}\text { Brief Resource } \\
\text { Description/Marker } \\
\text { Number }\end{array}$ & Time-Period \\
\hline Historical Marker & $180.5 \mathrm{ft}$. SE & $\begin{array}{c}\text { Benjamin Rush Milam } \\
(3370)\end{array}$ & 1835 \\
\hline Historical Marker & $323.2 \mathrm{ft} . \mathrm{S}$ & Emma Tenayuca (16245) & 1930 's \\
\hline
\end{tabular}

Table 3-3. National Register Districts within 1,000 feet (305-m) of the Area of Potential Effects.

\begin{tabular}{|c|c|c|c|}
\hline District Name & $\begin{array}{c}\text { Distance/Direction from } \\
\text { Project Area }\end{array}$ & Brief Description & Date Listed \\
\hline $\begin{array}{c}\text { San Antonio Downtown } \\
\text { and River Walk }\end{array}$ & $655 \mathrm{ft}$. SE & $\begin{array}{c}\text { San Antonio River walk } \\
\text { and surrounding blocks }\end{array}$ & 2018 \\
\hline $\begin{array}{c}\text { Main and Military Plazas } \\
\text { Historic District }\end{array}$ & $964 \mathrm{ft}$. SE & $18^{\text {th }}$ to $20^{\text {th }}$ centuries & 1979 \\
\hline
\end{tabular}

In 1993, archaeological monitoring of construction was conducted by the Center for Archaeological Research at the University of Texas at San Antonio at Milam Park (CAR UTSA) (THC 2019). During the monitoring the remains of Col. Benjamin Milam were located and exhumed. The remains were reinterred after the renovation of the park with the trinomial 41BX922 assigned to the site.

In 1995, CAR UTSA conducted archaeological investigations at Milam Park that consisted of shovel testing and monitoring of excavations during construction (THC 2019). During investigations, a historic burial was encountered with the remains exhumed and analyzed. The remains were found to be a 
Hispanic/Caucasian male between the ages of 30-34. Cultural material observed near the remains was consistent with the 1848-1853 use of the historic city cemetery.

In 2012, Atkins North America, Inc. (Atkins) archaeologists monitored excavations within Milam Park that resulted in the discovery of five possible grave markers (THC 2019). Excavations were conducted in an effort to determine if graves were still intact, however, the markers were determined to be modern in age and located within fill material approximately $10 \mathrm{~cm}$ above the natural clay surface.

In 2016, archaeological monitoring was conducted by Cox/McLain Environmental Consulting Inc. (CMEC) along North San Saba Street for approximately 700 feet between West Houston Street and West Commerce Street (THC 2019). Modern construction material was observed throughout the excavations with multiple utilities intersecting the APE. No indications of historic burials or intact archaeological deposits were observed. 


\section{CHAPTER 4. METHODS OF INVESTIGATION}

To ensure that the project met the requirements of the regulating agencies and that the construction did not impact significant archaeological resources, RKI archaeologists conducted archaeological monitoring for ground disturbing activities within the APE. Monitoring was conducted in order to document cultural materials, cultural features, and possibly the presence of human remains. All work complied with THC and CTA standards for the overall project.

In order to conduct this work, an RKI archaeologist stood on the edge of the active excavation, within a safe distance of heavy equipment, and observed the removal of soil matrix. RKI archaeologists were to systematically screen soil samples associated with intact Holocene-age deposits throughout the proposed APE. Specifically, 2 to 3 shovel-scoops of soil from the excavations were to be screened through $1 / 4$-inch mesh hardware cloth and examined for small pieces of cultural material (debitage, fire-cracked rock, bone etc.). Any recovered diagnostic cultural material was to be collected. No screening samples were to be taken from disturbed deposits, or deposits that predate the Holocene period. As no intact soils were encountered, no soil was screened. All impacted soils were thoroughly documented to fully describe the nature of the disturbance. If, during monitoring, clusters of artifacts are exposed, standard procedure calls for excavations to be temporarily suspended in the area to allow for careful inspection of the feature. No such clusters of artifacts were encountered.

The project adhered to a temporally diagnostic artifact collection only policy. No diagnostic artifacts were collected during the course of the investigations, thus, no artifacts will be curated at the completion of the project. The only materials to be processed and curated consists of documents and digital photographs produced during field investigations. All project-related documentation produced during monitoring activities was prepared for curation in accordance with federal regulation 36 CFR Part 79, and THC requirements for State Held-in-Trust collections. Field notes, field forms, photographs, and field drawings were placed into labeled archival folders and converted into electronic files. Digital photographs were printed on acid-free paper, labeled with archivally appropriate materials, and were placed in archival-quality plastic sleeves when needed. Ink-jet produced maps and illustrations were placed in archival quality plastic page protectors to prevent against accidental smearing due to moisture. A copy of the report and all digital materials were saved onto a CD and stored with field notes and documents. All 
Cultural Resources Monitoring for the San Antonio Water Systems Sewer Line Repair Project, San Antonio, Bexar County, Texas

project-related records will be submitted to the Center for Archaeological Research at the University of Texas at San Antonio for final curation. 


\section{CHAPTER 5. RESULTS OF INVESTIGATIONS}

RKEI conducted monitoring investigations for the SAWS Sewer Line Repairs Project on December 21 and 22, 2019 and January 14, 2020. Antonio Padilla served as Principal Investigator, and field work was conducted by Staff Archaeologist Lindy Martinez and Bioarchaeologist Susan Sincerbox. Monitoring investigations determined that the APE has been heavily impacted by previous construction-related events, as evinced by multiple utility lines intersecting the trench and fill material found within the trench. No intact soils were found to be present and no cultural materials or features were observed during monitoring investigations.

The APE is located within the northern lanes of West Houston Street, approximately 18 feet $(5.5 \mathrm{~m})$ east of its intersection with North San Saba Street, and extends into the sidewalk along the north side of West Houston Street (Figure 5-1). The project area is situated in a densely developed urban setting, bounded by the Santa Rosa Children's Hospital to the north and Milam Park to the south, and was covered by asphalt and concrete (Figures 5-2 and 5-3). Topography in the area of the APE was generally flat with no discernable slope.

During monitoring of the excavations within the APE, it was revealed that the entire APE has been heavily impacted by previous utility installations and construction events. Evidence of impacts to the APE consisted of asphalt, flowable fill, fill soil, construction gravels used as fill, and utilities found within the trench (Figure 5-4). Additional disturbances near the APE consisted of other utilities including communication lines, electrical lines, and gas lines directly north, east, and west of the trench.

Excavations began with the main trench located in northern lanes of West Houston Street, in order to locate the broken sewer line (see Figure 5-1). The trench measured approximately 26 feet $(7.9 \mathrm{~m})$ northsouth, 9 feet $(2.74 \mathrm{~m})$ east-west, and reached a depth of 6 feet $(1.8 \mathrm{~m})$ below surface. The typical main trench profile was:

- 0-3.9 inches $(0-10 \mathrm{~cm})$ - asphalt;

- $\quad 3.9$ inches -72 inches $(10-180 \mathrm{~cm})$ - flowable fill, brownish yellow (10YR 6/6 and 6/8) sandy loam with over 90 percent construction gravel inclusions, and existing utilities (Figure 5-5). 


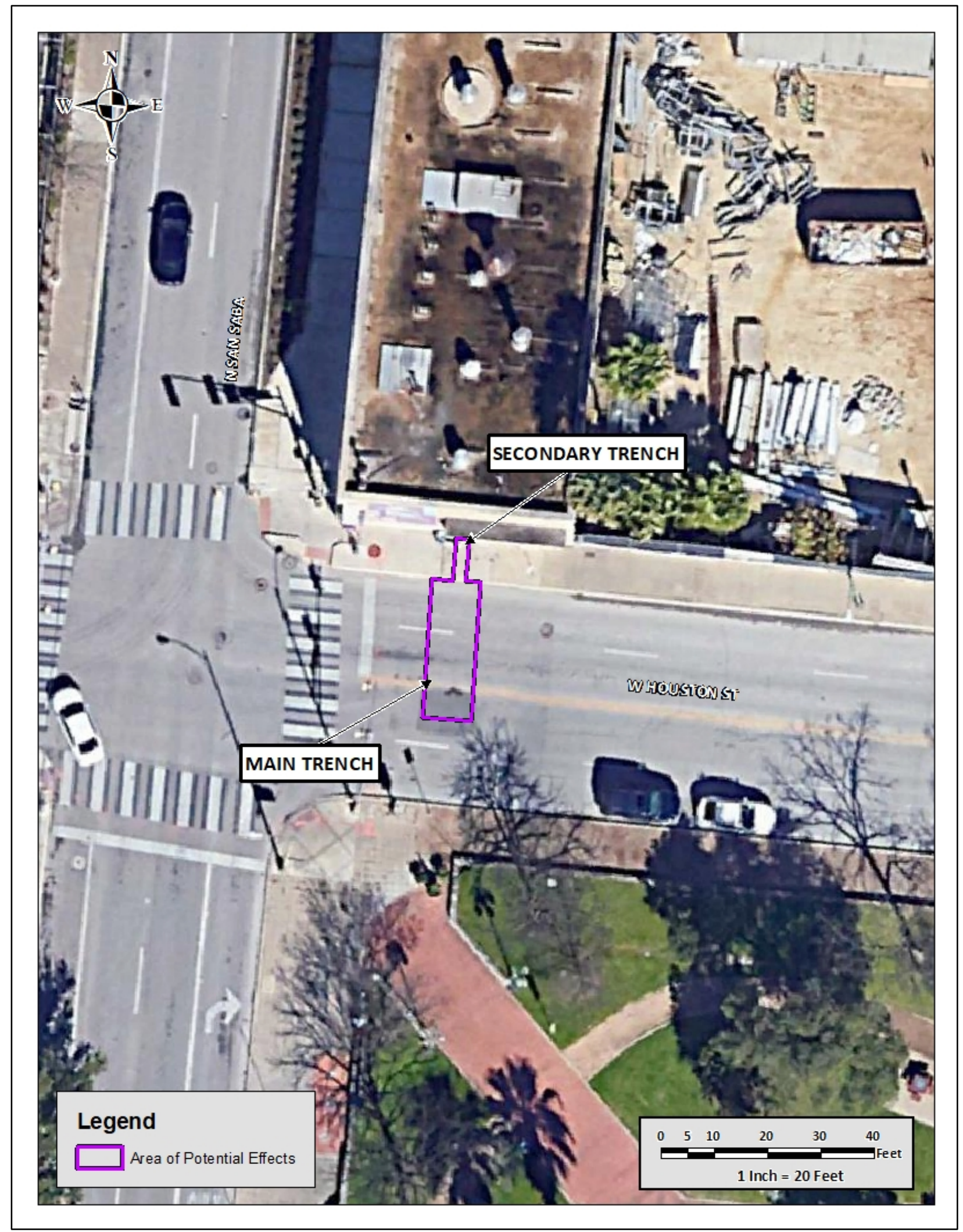

Figure 5-1. Results of monitoring investigations within the APE. 


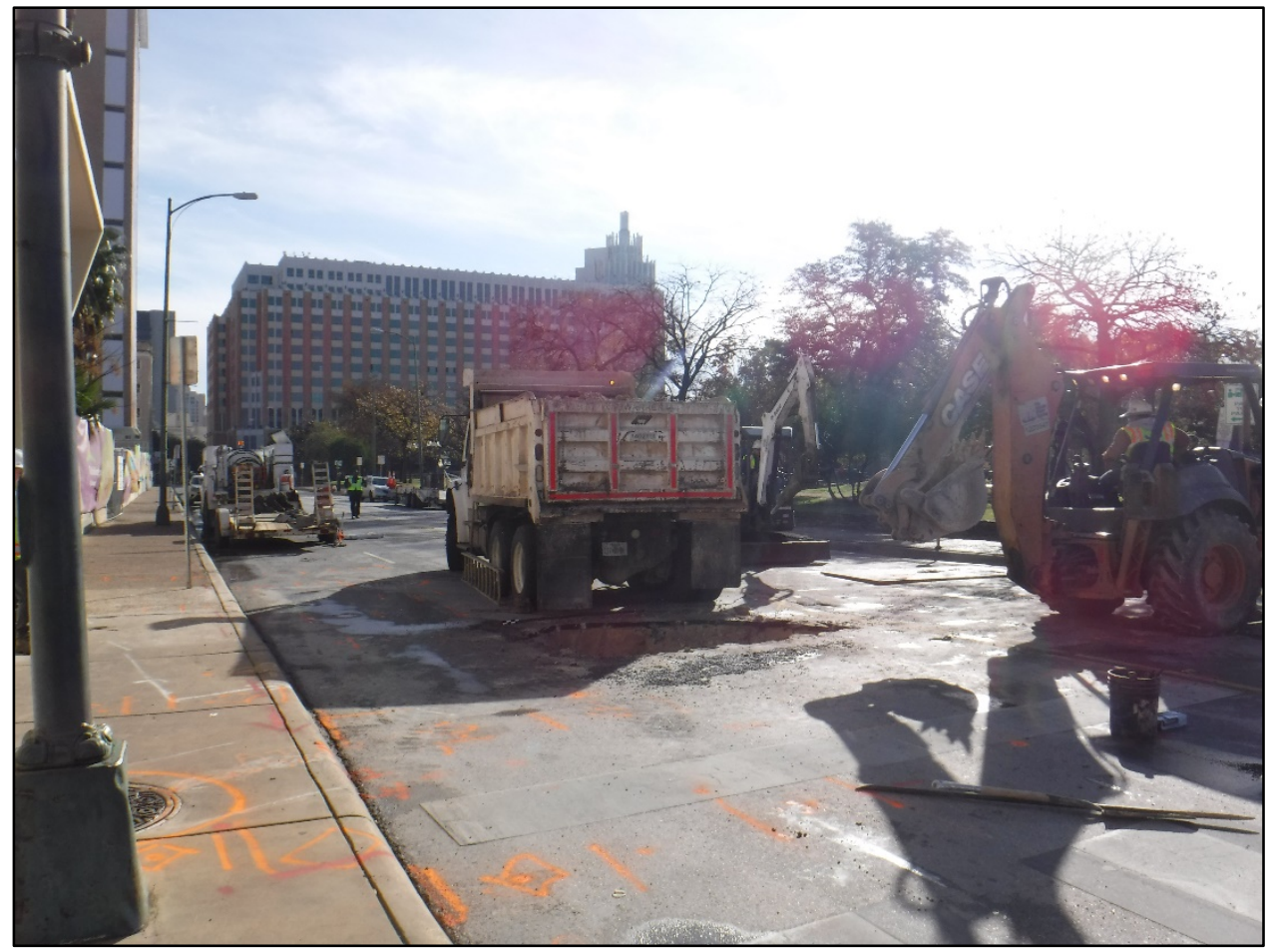

Figure 5-2. Overview of the Area of Potential Effects; facing east/southeast.

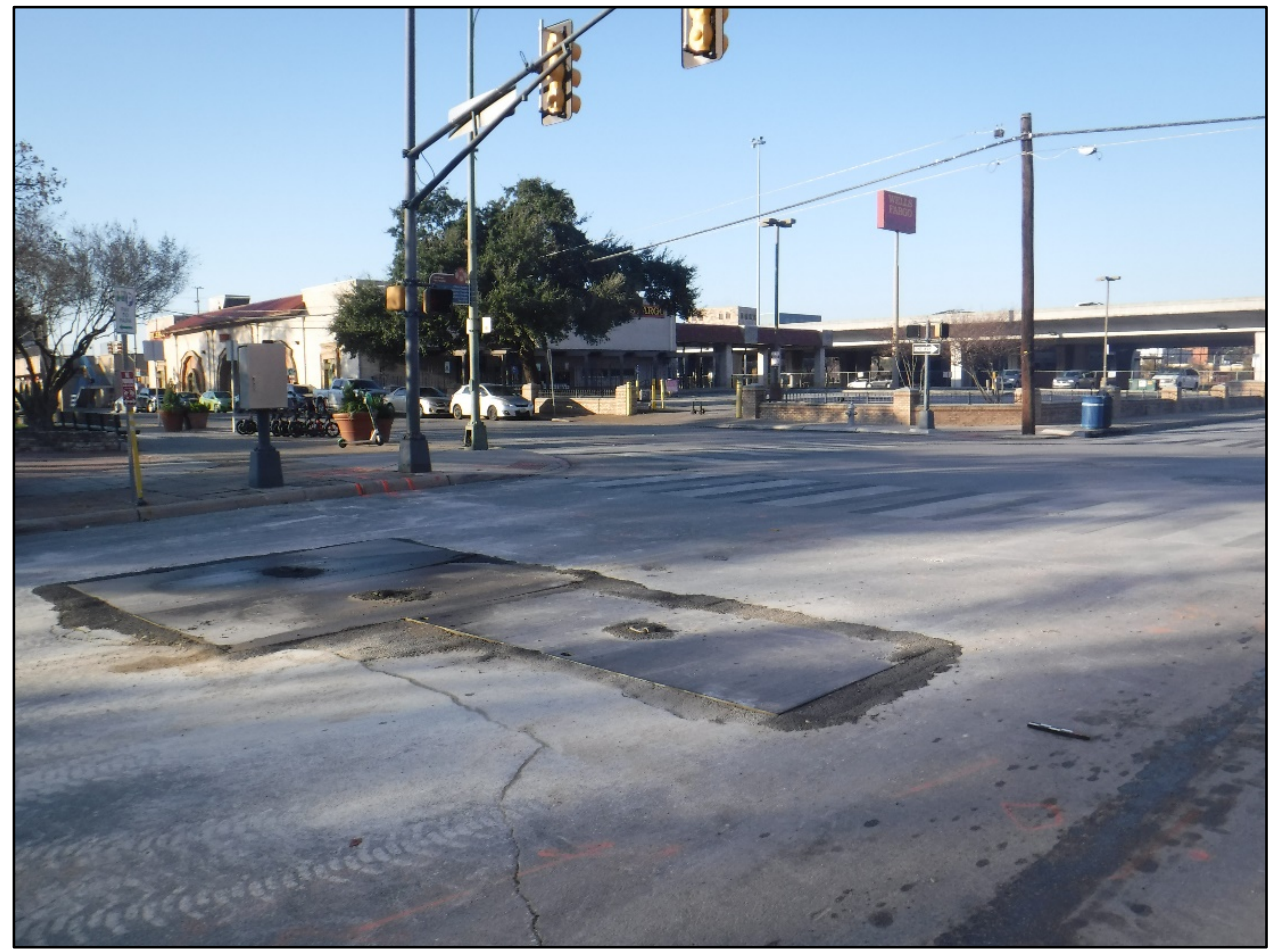

Figure 5-3. Overview of the Area of Potential Effects; facing southwest 


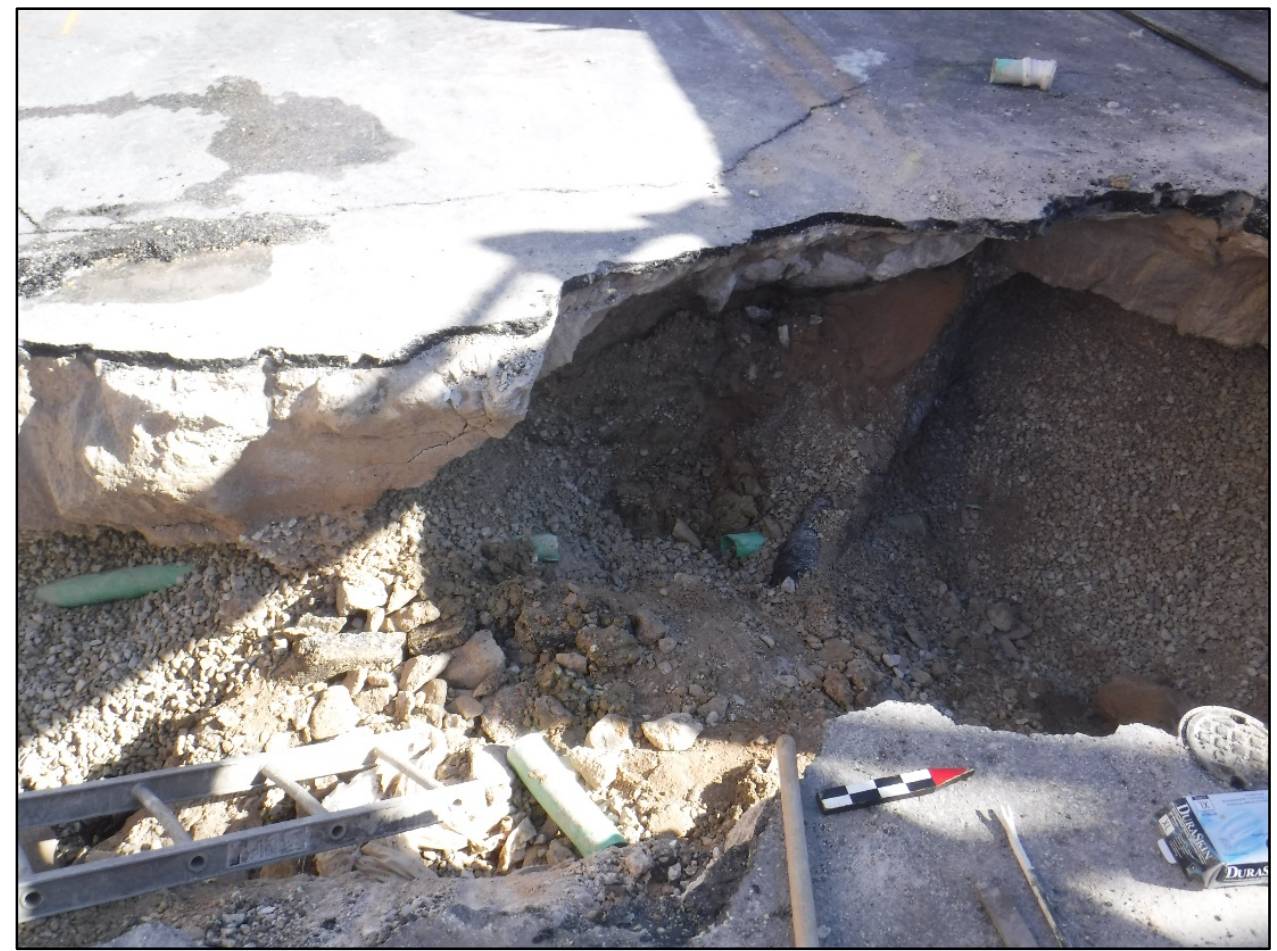

Figure 5-4. Disturbances observed during the excavation of the main trench; facing northwest.

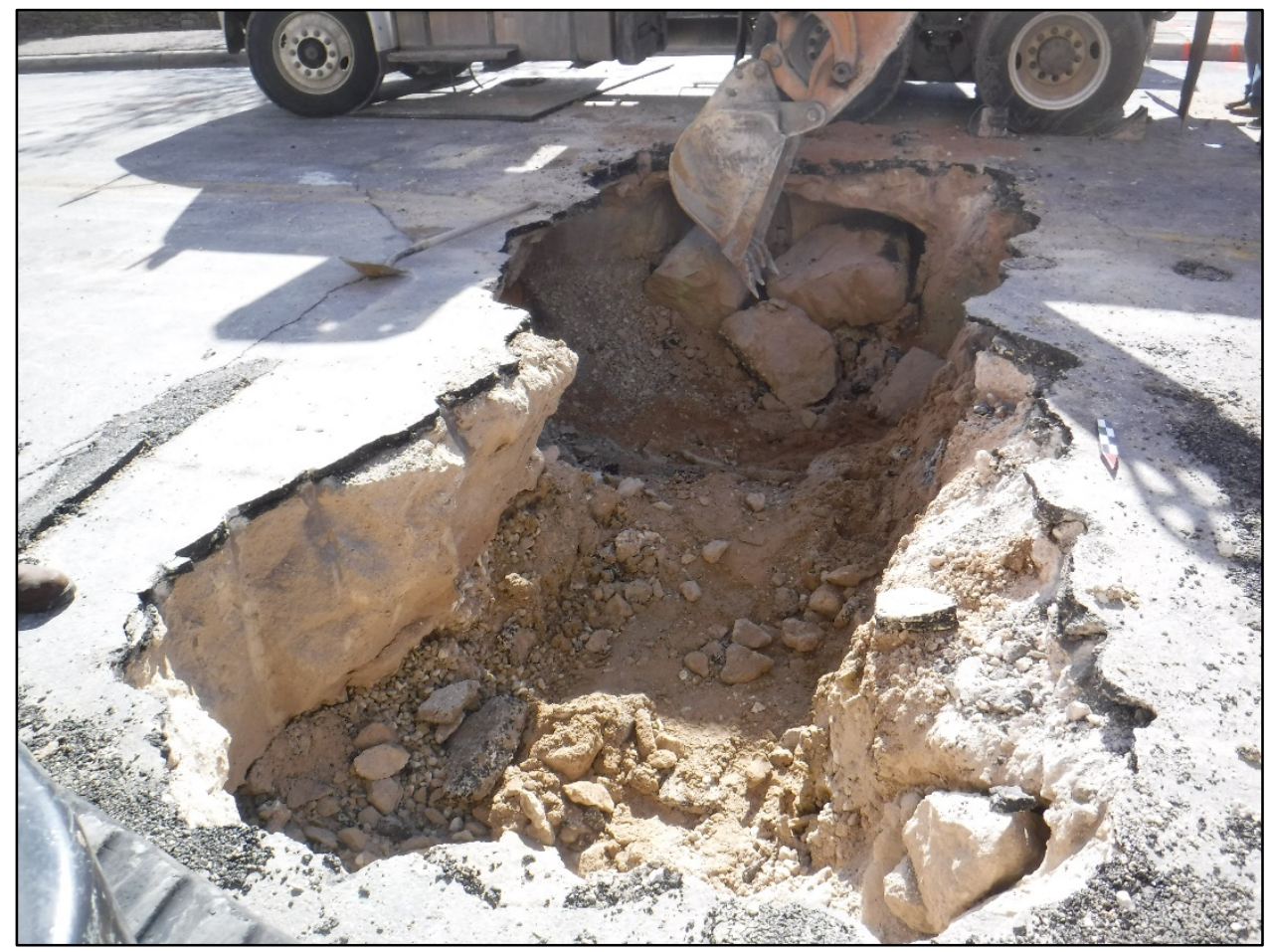

Figure 5-5. Figure 5-5. Typical profile of the main trench; facing south 
Following completion of the main trench, a secondary trench adjoining the main trench was excavated within the sidewalk north of West Houston Street (see Figure 5-1). The purpose of this additional adjoining trench was to connect the sewer line to the clean out located under the sidewalk north of West Houston Street. The additional trench measured approximately 8 feet $(2.4 \mathrm{~m})$ north-south by 2.5 feet $(0.8 \mathrm{~m})$ eastwest, and reached a depth of 1.7 feet $(0.5 \mathrm{~m})$ below surface. During the excavation of the trench, additional utilities were encountered (Figure 5-6). The average secondary trench profile was:

- $\quad 0-5$ inches $(0-13 \mathrm{~cm})$ - concrete;

- 5 inches-20.4 inches (13-51 cm) - flowable fill, brownish yellow (10YR 6/6 and 6/8) sandy loam with over 90 percent construction gravel inclusions, and existing utilities. (Figure 5-7).

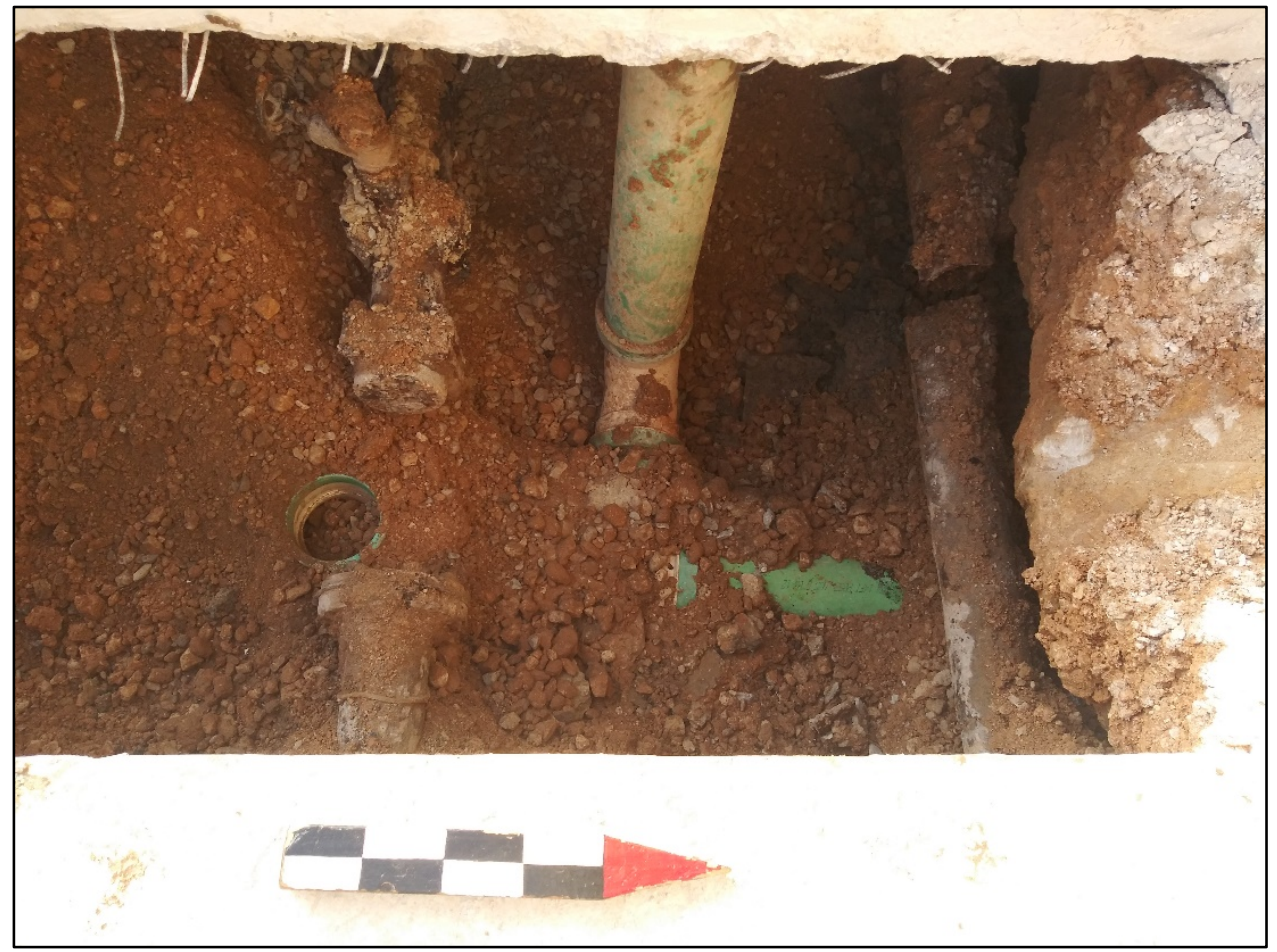

Figure 5-6. Construction gravels and utilities observed in the smaller trench, facing west.

During the investigations, it was discovered that the entire APE has been heavily impacted by previous construction events and the installation of utilities. Throughout the excavations, construction gravels were observed within the entire APE, reaching a depth of 6 feet $(1.8 \mathrm{~m})$ below surface, and several utilities were encountered. No intact soils were present within the trench. It appears that previous construction 
events and installation of utilities have removed all intact soils to the depths reached by the trench. Due to the absence of intact soils, no soils were screened. Additionally, no cultural materials or cultural features were observed during the monitoring of the excavations 


\section{CHAPTER 6. SUMMARY AND RECOMMENDATIONS}

Raba Kistner, Inc. (RKI) was contracted by K-Friese + Associates (CLIENT), on behalf of San Antonio Water Systems (SAWS), to conduct archaeological monitoring for emergency repairs to a collapsed sewer lateral within West Houston Street in Downtown San Antonio, Bexar County, Texas. The project involved the excavation of the area around the collapsed portion of the sewer lateral and the replacement of the damaged line. The project is located within the boundaries of a Catholic Cemetery and is between Milam Square (41BX991), which is a historic cemetery, and an area of the Children's Hospital of San Antonio where the first City Cemeteries have been documented. As such, the City of San Antonio (COSA) Office of Historic Preservation (OHP) required the monitoring of the excavation activities.

A desktop review was conducted to determine if any previously conducted archaeological investigations or any cultural resources had been documented within the APE. Review of the Texas Archeological Sites Atlas (Atlas), revealed that no previous archaeological surveys have been conducted and no previously recorded archaeological sites have been documented within the APE.

In December 2019 and January 2020, RKI conducted cultural resource monitoring for the SAWS Sewer Line Repair Project. The Area of Potential Effects (APE) consisted of a main trench that measured 26-feet $(7.9 \mathrm{~m})$-long north-south and 9-feet $(2.74 \mathrm{~m})$-wide east-west that was excavated to 6 feet $(1.8 \mathrm{~m})$ below surface within approximately the northern $2 / 3$ of West Houston Street, as well as a secondary trench that adjoined the northern extent of the main trench and measured approximately 8 feet $(2.4 \mathrm{~m})$ north-south, 2.5 feet $(0.8 \mathrm{~m})$ east-west and was excavated below the sidewalk north of West Houston Street to a depth of 1.7 feet $(0.5 \mathrm{~m})$ below surface

Excavations began with the main trench excavated in West Houston Street in order to locate and replace the broken sewer line and extended to the sidewalk north of West Houston Street. Excavations then concluded with the additional of the adjoining secondary trench. Archaeological monitors observed fill soils along with construction gravels and flowable fill and multiple utilities within the trench. No intact soils were observed during the excavations and no cultural deposits or features were observed during the excavations. It appears that construction of the utilities have removed all native soil to the depth of the trench. Due to the absence of intact soils, no screening of soils was conducted. 
RKI made a reasonable and good faith effort to identify cultural resources within the APE. No native soil, significant cultural material, or archaeological features were identified during the cultural resource monitoring. As a result, RKI does not recommend further archaeological investigations within the APE. However, should changes be made to the APE, further work may be required. No diagnostic artifacts were collected during the course of the investigations, thus, no artifacts will be curated at the completion of the project. All field records generated during this project will be permanently curated at the Center for Archaeological Research at the University of Texas at San Antonio. 


\section{REFERENCES CITED}

Barnes, V.E.

1983 Geologic Atlas of Texas, San Antonio Sheet. Bureau of Economic Geology, The University of Texas at Austin.

Bement, L.C

1991 The Thunder Valley Burial Cache: Group Investment in a Central Texas Sinkhole Cemetery. Plains Anthropologist 36(135):97-109.

Black, S. L.

1986 The Clemente and Herminia Hinojosa Site, 41JW8: A Toyah Horizon Campsite in Southern Texas. Special Report, No. 18. Center for Archaeological Research, The University of Texas at San Antonio.

1989a Environmental Setting. In From the Gulf to the Rio Grande: Human Adaptation in Central, South, and Lower Pecos Texas, by Thomas R. Hester, Stephen L. Black, D. Gentry Steele, Ben W. Olive, Anne A. Fox, Karl J. Reinhard, and Leland C. Bement, pp. 5-16. Research Series No. 33. Arkansas Archeological Survey, Fayetteville.

1989b Central Texas Plateau Prairie. In From the Gulf to the Rio Grande: Human Adaptation in Central, South, and Lower Pecos, Texas, by Thomas R. Hester, Stephen L. Black, D. Gentry Steele, Ben W. Olive, Anne A. Fox, Karl J. Reinhard, and Leland C. Bement, pp. 17-38. Research Series No. 33. Arkansas Archeological Survey, Fayetteville.

Black, S.L., and D.G. Creel

1997 The Central Texas Burned Rock Midden Reconsidered. In Hot Rock Cooking on the Greater Edwards Plateau: Four Burned Rock Midden Sites in West Central Texas, by Steve Black, Linda W. Ellis, Darrell G. Creel and Glenn T. Goode, pp.269-305. Studies in Archeology 2. Texas Archeological Research Laboratory, The University of Texas at Austin.

Blair, F.

1950 The Biotic Provinces of Texas. Texas Journal of Science 2(1):93-117.

Bousman, C.B

1998 Paleoenvironmental Change in Central Texas: The Palynological Evidence. Plains Anthropologist 43 (164):201-219.

Bousman, C.B, B.W. Baker, and A.C. Kerr

2004 Paleoindian Archeology in Texas. In The Prehistory of Texas, edited by Timothy Perttula, pp. 15-97. Texas A\&M University Press, College Station.

Bureau of Economic Geology

1983 Geologic Atlas of Texas - San Antonio Sheet. Bureau of Economic Geology, The University of Texas at Austin. 
Collins, M.B.

1995 Forty Years of Archeology in Central Texas. Bulletin of the Texas Archeological Society 66:361400.

2004 Archeology in Central Texas. In Prehistory of Texas, edited by Timothy K. Perttula, pp.101126. Texas A\&M University Press. College Station, Texas.

Collins, M.B., J. Guy, and S.W. Dial

1998 The Archaic Period, 8800 to 1300 BP. In Wilson-Leonard: An 11,000-year Archaeological Record of Hunter-Gatherers on Central Texas. Volume I: Introduction, Background, and Syntheses. Edited by Michael B. Collins. Studies in Archaeology 31. Texas Archaeological Research Laboratory, The University of Texas at Austin.

Collins, M.B., D.B. Hudler, and S.L. Black

2003 Pavo Real (41BX52): A Paleoindian and Archaic Camp and Workshop on the Balcones Escarpment, South-Central, Texas. Studies in Archeology 41, Texas Archeological Research Laboratory, The University of Texas at Austin. Archeological Studies Program, Report 50, Environmental Affairs Division, Texas Department of Transportation, Austin.

Cox, I. Wayne, Edgar D. Johnson, and C. Britt Bousman

1999 Excavations for the Upper Labor Dam Site, Brackenridge Park, San Antonio, Bexar County, Texas. Archaeological Survey Report, No. 268. Center for Archaeological Research at the University of Texas at San Antonio, San Antonio.

2005 The Spanish Acequias of San Antonio. Maverick Publishing Company, San Antonio.

Dobkins, B.E.

1959 The Spanish Element in Texas Water Law. University of Texas Press, Austin.

de la Teja, J.F.

1995 San Antonio de Bexar: A Community on the New Spain's Northern Frontier. The University of New Mexico Press, Albuquerque.

Edwards Aquifer Website.net, The

2019 Regional Climate and Water Availability. Available at: https://www.edwardsaquifer.net/ climate.html. Accessed January 21, 2020.

Ferring, C.R.

2001 The Archaeology and Paleoecology of the Aubrey Clovis Site (41DN479) Denton County, Texas. Center for Environmental Archaeology. Department of Geography, University of North Texas.

Griffin, G. E., and J. M. Omernik

2019 Ecoregions of Texas (EPA). United States Environmental Protection Agency. Available at: http:/www.ecoearth.ort/article/Ecoregions_of_Texas (EPA). Accessed January 21, 2020.

Hadley, D., J.H. Naylor, M.K. Schuetz-Miller 
1997 The Presidio and Militia on the Northern Frontier of New Spain: A Documentary History, Volume Two, Part Two: The Central Corridor and Texas Corridor, 1700-1765. Translation on file at RKEI. University of Arizona Press.

Habig, M.A.

1968 The Alamo Chain of Missions: A History of San Antonio's Five Old Missions. Franciscan Herald Press, Chicago.

Hester, T.R.

1978 Early Human Occupation in South Central and Southwestern Texas; Preliminary Papers on the Baker Cave and St. Mary's Hall Sites. Manuscript on File. Center for Archaeological Research, The University of Texas at San Antonio.

1990 Plainview Artifacts at the St. Mary's Hall Site, South Central Texas. Current Research in the Pleistocene 7:14-17.

2004 The Prehistory of South Texas. In Prehistory of Texas, edited by Timothy K. Perttula, pp.127151. Texas A\&M University Press. College Station, Texas.

Highley, C.L., C. Graves, C. Land, and G. Judson

1978 Archeological Investigations at Scorpion Cave (41ME7) Medina County, Texas. Bulletin of the Texas Archeological Society 49:139-194.

Huebner, J.A.

1991 Late Prehistoric Bison Populations in Central and Southern Texas. Plains Anthropologist 36(137):343-358.

Ivey, J. E.

1984 The San Antonio Missions. Unpublished Manuscript. On file at the Center for Archaeological Research, The University of Texas at San Antonio.

Johnson, L., and G.T. Goode

1994 A New Try at Dating and Characterizing Holocene Climates, as well as Archaeological Periods, on Eastern Edwards Plateau. Bulletin of the Texas Archaeological Society 65:1-51.

Johnson, L, Jr., D. A. Suhm, and C. D. Tunnell

1962 Salvage Archeology of Canyon Reservoir: The Wunderlich, Footbridge, and Oblate Sites. Texas Memorial Museum Bulletin No. 5, The University of Texas at Austin.

Kalter, A.J., R.M. Rogers, and M.N. Smith

2005 Analysis and Reporting for 41FY135, the Sandbur Site, Fayette County, Texas. PBS\&J, Document No. 020388. Archeological Studies Program Report No. 73. Texas Department of Transportation. Austin.

Kottek, M., J. Grieser, C. Beck, B. Rudolf, and F. Rubel

2019 World Maps of Köppen-Geiger Climate Classification Updated. Available at http://koeppengeiger.vu-wien.ac.at/present.htm. Accessed January 22, 2020. 
Mauldin, R.P., and D.L. Nickels

2001 An Archaeological Survey of Twin Buttes Reservoir, Tom Green County, Texas. Archaeological Survey Report, No. 300. Center for Archaeological Research, The University of Texas at San Antonio.

Mauldin, R.P., D.L. Nickels, and C.J. Broehm

2003 Archaeological Testing at Determine the National Register Eligibility Status of 18 Prehistoric Sites on Camp Bowie, Brown County, Texas (Volume 1 and Volume 2). Archaeological Survey Report, No. 334. Center for Archaeological Research, The University of Texas at San Antonio.

Meltzer, D.J., and M.R. Bever

1995 Paleoindians of Texas: An Update on the Texas Clovis Fluted Point Survey. Bulletin of the Texas Archeological Society 66:47-81.

Montejano, D.

1987 Anglos and Mexicans in the Making of Texas, 1836-1986. University of Texas Press, Austin.

Natural Resources Conservation Service (NRCS)

2019 Soil Survey Staff, Natural Resources Conservation Service, United States Department of Agriculture. Web Soil Survey of Bexar County. Available at http://websoilsurvey.nrcs.usda.gov/. Accessed January 21, 2020.

Nickels, D.L., C.B. Bousman, J.D. Leach, and D.A. Cargill

1998 Test Excavations at the Culebra Creek Site, 41BX126, Bexar County, Texas. Archaeological Survey Report, No. 265. Center for Archaeological Research, The University of Texas at San Antonio.

NOAA Climate

2019 Data Snapshots: Average Monthly Temperature. Climate.gov. Available at: https://www.climate.gov/maps-data/data-snapshots/averagetemp-monthly-cmb-2003-0800 ?theme=Temperature. Accessed January 21, 2020.

Patterson, L.W. 1988 Chronology of Arrow Point Types in South Texas. La Tierra 15(4):29-33.

Porter, C.R., Jr.

2009 Spanish Water, Anglo Water: Early Development in San Antonio. Texas A\&M University Press, College Station.

Powell, J.F., and D.G. Steele

1994 Diet and Health of Paleoindians: An Examination of Early Holocene Human Dental Remains. In Paleonutrition: The Diet and Health of Prehistoric Americans. Edited by K.D. Sobolik, pp. 176-192. Occasional Paper No. 22. Carbondale: Center for Archaeological Investigations, Southern Illinois University, Carbondale. 
Prewitt, E.R.

1981 Cultural Chronology in Central Texas. Bulletin of the Texas Archaeological Society. 52:65-89.

1985 From Circleville to Toyah: Comments on Central Texas Chronology. Bulletin of the Texas Archeological Society 54:201-238.

Quigg, J.M., C. Lintz, F.M. Oglesby, A.C. Earls, C.D. Frederick, W.N. Trierweiler, D. Owsley, and K.W. Kibler 1993 Historic and Prehistoric Data Recovery at Palo Duro Reservoir, Hansford County, Texas. Technical Report 485. Mariah Associates, Inc., Austin.

Ricklis, R.A.

1995 Prehistoric Occupation of the Central and Lower Texas Coast: A Regional Overview. Bulletin of the Texas Archeological Society 66:265-300.

Schuetz, M.K.

1968 The History and Archaeology of Mission San Juan Capistrano, San Antonio, Texas. Volume 1. Archeology Program Report Number 10. State Building Commission, Austin.

Scurlock, D., A. Benavides, Jr., D. Isham, and J. Clark, Jr.

1976 An Archeological and Historical Survey of the Proposed Mission Parkway, San Antonio, Texas. Archeology Survey Report No. 17, Texas Historical Commission, Austin.

Skinner, S.A.

1981 Aboriginal Demographic Changes in Central Texas. Plains Anthropologist 26(92):111-118.

Sorrow, W. M., H. J. Shafer, and R. E. Ross

1967 Excavations at Stillhouse Hollow Reservoir. Papers of the Texas Archeological Salvage Project 11. The University of Texas at Austin, Austin.

Southern Regional Climate Center

2019 Monthly Climate Summary. Available at www.srcc.Isu.edu/. Accessed January 21, 2020.

Story, D. A.

1985 Adaptive Strategies of Archaic Cultures of the West Gulf Coastal Plain. In Prehistoric Food Production in North America, edited by R. I. Ford, pp. 19-56. Anthropological Papers 75. Museum of Anthropology, University of Michigan, Ann Arbor.

Suhm, D. A.

1957 Excavations at the Smith Rockshelter, Travis County, Texas. Texas Journal of Science 9:26-58.

1960 A Review of Central Texas Archeology. Bulletin of the Texas Archeological Society 29:63-107.

Suhm, D.A., A.D. Krieger, and E.B. Jelks 
1954 An Introductory Handbook of Texas Archeology. Bulletin of the Texas Archeological Society 25 .

Texas Historical Commission (THC)

2019 Texas Archeological Sites Atlas. http://nueces.thc.state.tx.us/. Accessed January 21, 2020.

Thoms, A.V., D.D. Keuhn, B.W. Olive, J.E. Dockall, P.A. Clabaugh an R.D. Mandel

1996 Early and Middle Holocene Occupations at the Richard Beene Site: The 1995 Southern Texas Archaeological Society Association Field School Project. La Tierra (23) 4:1-36.

Toomey, R.S., M.D. Blum, and S. Valastro, Jr.

1993 Late Quaternary Climates and Environments of the Edwards Plateau, Texas. Global and Planetary Change 7:299-320.

Weatherspark.com

2019 Average Weather in San Antonio. Available at : https://weatherspark.com/y/7137/AverageWeather-in-San-Antonio-Texas-United-States-Year-Round Accessed January 21, 2020.

Weir, F. A.

1976 The Central Texas Archaic. Ph.D. dissertation, Department of Anthropology, Washington State University, Pullman.

Winkler, B.A.

1982 Wild Plant Foods of the Desert Gatherers of West Texas, New Mexico, and Northern Mexico: Some Nutritional Values. Unpublished Master's Thesis, Department of Anthropology, The University of Texas at Austin. 